\title{
Synthesis of $\mathrm{CoO}_{\boldsymbol{x}}-\mathrm{TiO}_{2}$ Catalysts and Its Application for Low-Temperature CO Oxidation
}

\author{
Der-Shing Lee and Yu-Wen Chen \\ Department of Chemical and Materials Engineering, National Central University, Chung-Li 320, Taiwan \\ Correspondence should be addressed to Yu-Wen Chen; ywchen@ncu.edu.tw
}

Received 10 January 2013; Revised 21 January 2013; Accepted 31 January 2013

Academic Editor: Adel A. Ismail

Copyright (c) 2013 D.-S. Lee and Y.-W. Chen. This is an open access article distributed under the Creative Commons Attribution License, which permits unrestricted use, distribution, and reproduction in any medium, provided the original work is properly cited.

\begin{abstract}
A series of $\mathrm{Au} / \mathrm{CoO}_{x}-\mathrm{TiO}_{2}$ with various $\mathrm{Co} / \mathrm{Ti}$ ratios prepared. $\mathrm{CoO}_{x} / \mathrm{TiO}_{2}$ was prepared by incipient wetness impregnation with aqueous solution of cobalt nitrate. Au catalysts were prepared by deposition-precipitation (DP) method at $\mathrm{pH} 7$ and $338 \mathrm{~K}$. The catalysts were characterized by inductively coupled plasma-mass spectrometry, temperature programming reduction, Xray diffraction, transmission electron microscopy, high-resolution transmission electron microscopy, and X-ray photoelectron spectroscopy. The reaction was carried out in a fixed bed reactor with a feed containing $1 \% \mathrm{CO}$ in air at weight hourly space velocities of $120,000 \mathrm{~mL} / \mathrm{h}$ g and $180,000 \mathrm{~mL} / \mathrm{h} \mathrm{g}$. High gold dispersion and narrow particle size distribution were obtained by DP method. The addition of $\mathrm{CoO}_{x}$ into $\mathrm{Au} / \mathrm{TiO}_{2}$ enhanced the activity of $\mathrm{CO}$ oxidation significantly. $\mathrm{Au} / 5 \% \mathrm{CoO}_{x}-\mathrm{TiO}_{2}$ had the highest catalyst among all the catalysts. $\mathrm{CoO}_{x}$ was mainly in the form of nanosize $\mathrm{Co}_{3} \mathrm{O}_{4}$ which could stabilize the Au nanoparticles. $\mathrm{CoO} x$ donated partial electrons to $\mathrm{Au}$. The interactions among $\mathrm{Au}, \mathrm{CoO}_{x}$, and $\mathrm{TiO}_{2}$ account for the high catalytic activity for $\mathrm{CO}$ oxidation.
\end{abstract}

\section{Introduction}

Carbon monoxide is a toxic, colorless, and tasteless gas. It can cause human being to die in short time. Low-temperature $\mathrm{CO}$ oxidation has been extensively studied because it plays an important role in gas purification in $\mathrm{CO}_{2}$ lasers, $\mathrm{CO}$ gas sensors, air purification devices, and removing trace quantity of $\mathrm{CO}$ from ambient air in enclosed atmospheres such as submarines and aircrafts [1-3]. When gold is deposited as nanoparticles on metal oxides, it exhibits surprisingly high catalytic activity for $\mathrm{CO}$ oxidation at a temperature as low as $100 \mathrm{~K}$. The activity of gold catalysts also depends on support, preparation method and condition. Haruta and coworkers [1-4] found the high activity of supported gold catalysts for low-temperature CO oxidation. It is believed to occur on the metal-support interface. Cobalt oxides are good in removing the $\mathrm{CO}, \mathrm{NO}_{x}$, and $\mathrm{VOC}_{\mathrm{s}}$ in the air. The cobalt oxides have different oxidation states, such as $\mathrm{CoO}_{2}, \mathrm{Co}_{2} \mathrm{O}_{3}, \mathrm{Co}_{3} \mathrm{O}_{4}$, and $\mathrm{CoO}$. The $\mathrm{Co}_{3} \mathrm{O}_{4}$ and $\mathrm{CoO}$ are more stable than the others. For the activity of $\mathrm{CO}$ oxidation reaction, the $\mathrm{Co}_{3} \mathrm{O}_{4}$ has a higher activity than $\mathrm{CoO}[5-8]$. The $\mathrm{Co}_{3} \mathrm{O}_{4}$ has been reported to be an effective catalyst in the oxidation reaction.
Furthermore, it has also been used as a support for gold. $\mathrm{CoO}_{x}$ was reported to be active for $\mathrm{CO}$ oxidation, but not very active at room temperature. Although $\mathrm{CO}$ oxidation on $\mathrm{Au}$ catalysts has been extensively studied [9-13], none the of researchers has used $\mathrm{CoO}_{x}-\mathrm{TiO}_{2}$ binary oxide as the support.

In this study, the effect of the content of $\mathrm{CoO}_{x}$ in $\mathrm{Au} /$ $\mathrm{CoO}_{x}-\mathrm{TiO}_{2}$ on the activity of $\mathrm{CO}$ oxidation was elucidated. The catalysts were characterized by various techniques.

\section{Experimental}

2.1. Catalysts Preparation. Reagents used here were analytical grade. $\mathrm{P} 25 \mathrm{TiO}_{2}$ was obtained from Evonik Degussa Company. $\mathrm{CoO}_{x}-\mathrm{TiO}_{2}$ was prepared by incipient wetness impregnation method. Various amounts of aqueous $\mathrm{Co}\left(\mathrm{NO}_{3}\right)_{2}$ solution were added into $\mathrm{TiO}_{2}$ powder under stirring. The traditional incipient wetness impregnation was used in the preparation. The pore volume of $\mathrm{TiO}_{2}$ was $0.6 \mathrm{~cm}^{3} / \mathrm{g}$. It was calcined in air at $473 \mathrm{~K}$ for $4 \mathrm{~h}$. The temperature was not too high to have Crystalline phase of $\mathrm{Co}_{3} \mathrm{O}_{4}$. Au was then added by deposition-precipitation (DP) technique. An aqueous 


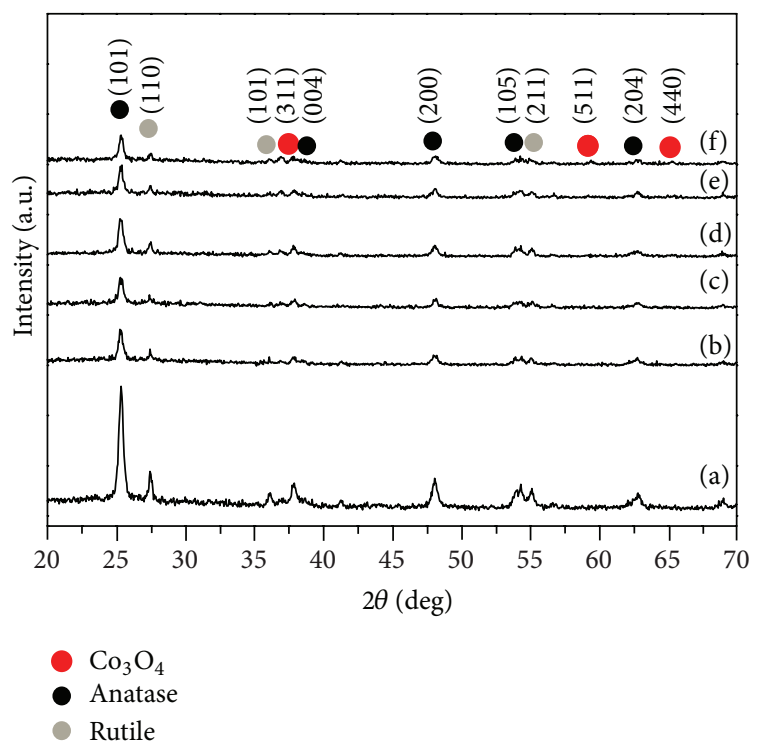

FIgURE 1: XRD of patterns $\mathrm{Au} / \mathrm{CoO}_{x}-\mathrm{TiO}_{2}$, (a) $\mathrm{Au} / \mathrm{TiO}_{2}$, (b) $\mathrm{Au} /$ $1 \% \mathrm{CoO}_{x}-\mathrm{TiO}_{2}$, (c) $\mathrm{Au} / 3 \% \mathrm{CoO}_{x}-\mathrm{TiO}_{2}$, (d) $\mathrm{Au} / 5 \% \mathrm{CoO}_{x}-\mathrm{TiO}_{2}$, (e) $\mathrm{Au} / 8 \% \mathrm{CoO}_{x}-\mathrm{TiO}_{2}$, and (f) $\mathrm{Au} / 10 \% \mathrm{CoO}_{x}-\mathrm{TiO}_{2}$.

TABLE 1: Actual gold loading on support of the catalysts.

\begin{tabular}{lcccc}
\hline \multirow{2}{*}{ Catalyst } & \multicolumn{2}{c}{ Nominal (wt.\%) } & \multicolumn{2}{c}{ Actual (wt.\%) } \\
& $\mathrm{Au}$ & $\mathrm{Co}$ & $\mathrm{Au}$ & $\mathrm{Co}$ \\
\hline $\mathrm{Au} / \mathrm{TiO}_{2}$ & 1 & 0 & 0.744 & 0.00 \\
$\mathrm{Au} / 1 \% \mathrm{CoO}_{x}-\mathrm{TiO}_{2}$ & 1 & 1 & 0.427 & 0.45 \\
$\mathrm{Au} / 3 \% \mathrm{CoO}_{x}-\mathrm{TiO}_{2}$ & 1 & 3 & 0.721 & 3.24 \\
$\mathrm{Au} / 5 \% \mathrm{CoO}_{x}-\mathrm{TiO}_{2}$ & 1 & 5 & 0.701 & 5.25 \\
$\mathrm{Au} / 8 \% \mathrm{CoO}_{x}-\mathrm{TiO}_{2}$ & 1 & 8 & 0.710 & 8.89 \\
$\mathrm{Au} / 10 \% \mathrm{CoO}_{x}-\mathrm{TiO}_{2}$ & 1 & 10 & 0.791 & 10.6 \\
\hline
\end{tabular}

solution of $\mathrm{HAuCl}_{4}$ was added into the solution containing suspended $\mathrm{CoO}_{x}-\mathrm{TiO}_{2}$ support at a rate of $10 \mathrm{~mL} / \mathrm{min}$. The temperature of the solution was maintained at $338 \mathrm{~K} .1 \mathrm{M}$ $\mathrm{NH}_{4} \mathrm{OH}$ solution was used to adjust the $\mathrm{pH}$ value to 7 . After aging for $2 \mathrm{~h}$, the precipitate was filtered and washed with hot water until no chloride ions were detected. Finally, the sample was dried overnight in air at $353 \mathrm{~K}$ and then calcined at $453 \mathrm{~K}$ for $4 \mathrm{~h}$. This temperature was high enough to reduce cationic gold to metallic gold, but not too high to cause the sintering of gold particles.

2.2. Characterization. The catalysts were characterized by inductively coupled plasma-mass spectrometry (ICP-MS), X-ray diffraction (XRD), transmission electron microscopy (TEM), high-resolution transmission electron microscopy (HRTEM), and X-ray photoelectron spectroscopy (XPS).

The exact gold content was analyzed by ICP-MS (PESCIEX ELAN 6100 DRC). The cross flow pneumatic nebulizer and double-pass-scott-type spray chamber were used to nebulize the samples. The solution was transferred by peristaltic pump, and the nebulizer used to nebulize the samples into spray chamber detected by DRC-ICP-MS. A CEM MDS-2000
(CEM, Matthews, NC, USA) microwave apparatus equipped with Teflon vessels was used to digest the powder samples.

XRD analysis was performed on a Siemens D500 powder diffractometer using $\mathrm{CuK} \alpha 1$ radiation $(0.15405 \mathrm{~nm})$ at a voltage and current of $40 \mathrm{kV}$ and $40 \mathrm{~mA}$, respectively. The sample was scanned over the range of $2 \theta=20-70^{\circ}$ at a rate of $0.05^{\circ} / \mathrm{min}$ to identify the crystalline structure. The sample was prepared as a thin layer on a sample holder.

The morphologies and particle sizes of the samples were determined by TEM on a JEM-2000 EX II operated at $160 \mathrm{kV}$ and HRTEM on a JEOL JEM-2010 operated at $160 \mathrm{kV}$. Initially, a small amount of the sample was placed into a sample tube filled with a $95 \%$ methanol solution, and after agitating under ultrasonic environment for $10 \mathrm{~min}$, one drop of the dispersed slurry was dipped onto a carbon-coated copper mesh (no. 300) (Ted Pella Inc., CA, USA), and dried in an oven for $1 \mathrm{~h}$. Images were recorded digitally with a Gatan slow scan camera (GIF). Based on the several images of TEM or HRTEM, more than 100 particles were counted and the size distribution graph was obtained.

The XPS spectra were recorded with a Thermo VG Scientific Sigma Probe spectrometer. The XPS spectra were collected using $\mathrm{AlK}_{\alpha}$ radiation at a voltage and current of $20 \mathrm{kV}$ and $30 \mathrm{~mA}$, respectively. The base pressure in the analyzing chamber was maintained in the order of $10^{-7} \mathrm{~Pa}$. The spectrometer was operated at $23.5 \mathrm{eV}$ pass energy and the binding energy was corrected by contaminant carbon $\left(\mathrm{C}_{1 \mathrm{~s}}=\right.$ $284.5 \mathrm{eV}$ ) in order to facilitate the comparisons of the values among the catalysts and the standard compounds. Peak fitting was done using XPSPEAK 4.1 with Shirley background and $30: 70$ Lorentzian/Gaussian convolution product shapes. The full width at half maximum (FWHM) in the entire spectra was $1.3 \mathrm{eV}$.

2.3. CO Oxidation. The catalytic activities of $\mathrm{CO}$ oxidation in air were carried out in a downward, fixed-bed continuousflow, Pyrex glass tubular reactor loaded with $0.05 \mathrm{~g}$ of catalyst. The reactant gas containing $1 \% \mathrm{CO}$ in air was fed into a reactor with a flow rate of $100 \mathrm{~mL} / \mathrm{min}$ (WHSV $=120,000 \mathrm{~mL} / \mathrm{h} \cdot \mathrm{g}$ ) or $150 \mathrm{~mL} / \mathrm{min}$ (WHSV $=180,000 \mathrm{~mL} / \mathrm{h} \cdot \mathrm{g}$ ). The outlet gas was analyzed by a gas chromatograph (China Chromatography $8700 \mathrm{~T}$ ) equipped with a MS-5A column and a thermal conductivity detector. Calibration of the gases was done with a standard gas containing the known concentration of the components. The $\mathrm{CO}$ conversion was calculated as follows:

$$
\text { CO conversion }\left(X_{\mathrm{CO}} \%\right)=\frac{[\mathrm{CO}]_{\text {in }}-[\mathrm{CO}]_{\text {out }}}{[\mathrm{CO}]_{\text {in }}} * 100 \% \text {, }
$$

where $[\mathrm{CO}]$ is the concentration of $\mathrm{CO}$.

\section{Results and Discussion}

3.1. ICP-MS. The elemental analysis results in Table 1 show the real gold and cobalt loadings in the catalysts. In this study, the original amount of gold in the solution was $1 \mathrm{wt} . \%$, and the content of cobalt was between 1 and $10 \mathrm{wt} . \%$. Only about $70 \%$ of Au was deposited by DP process, in agreement 

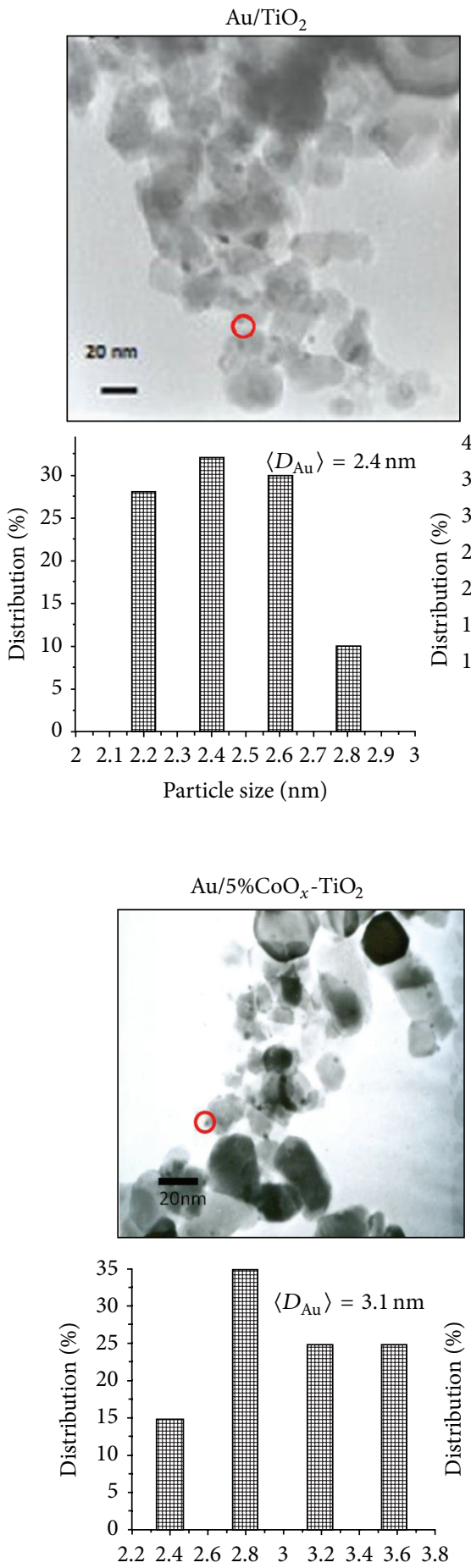

Particle size (nm)
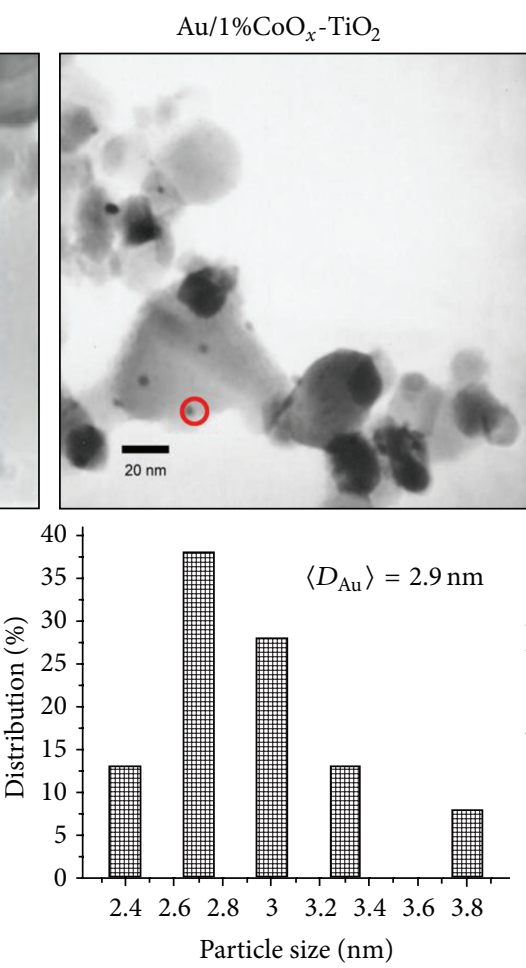

(a)
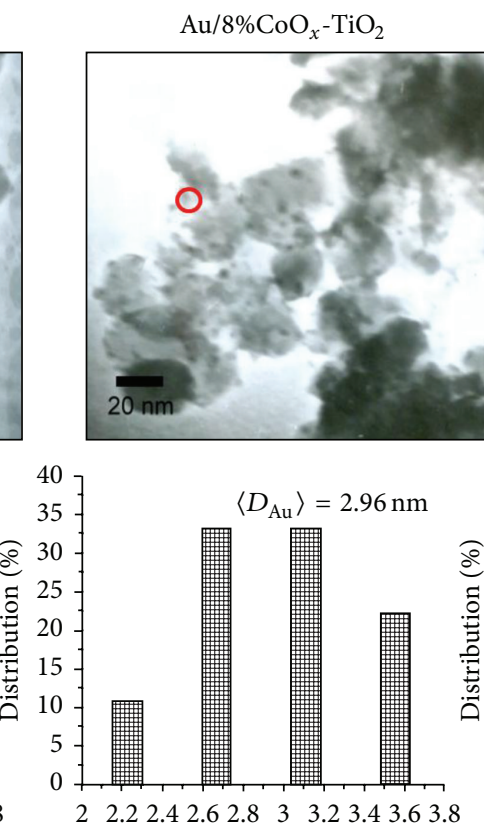

Particle size (nm)

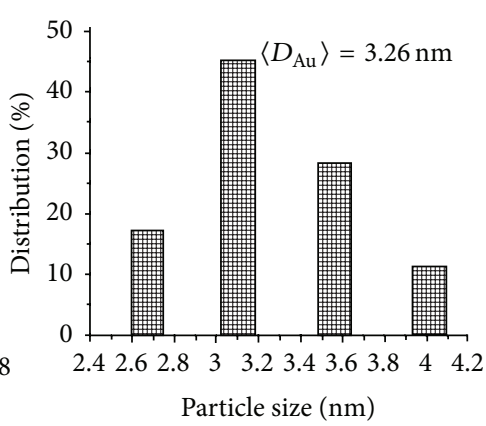

(b)
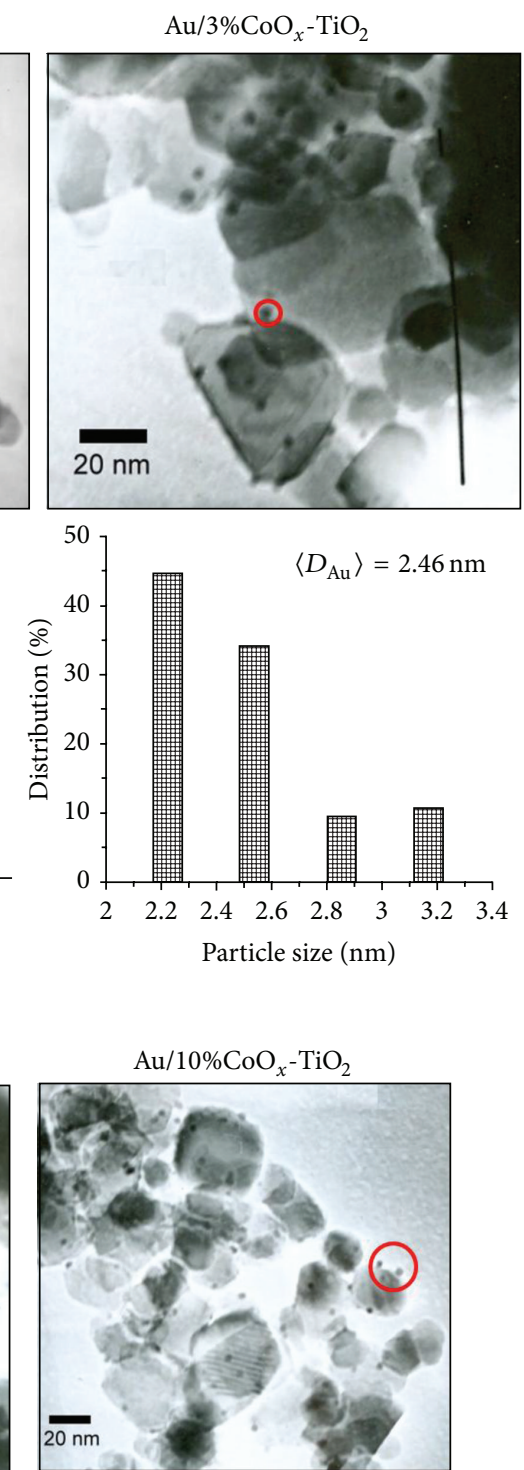

$\mathrm{Au} / 10 \% \mathrm{CoO}_{x}-\mathrm{TiO}_{2}$

(1)

Figure 2: The TEM image and Au particle size distribution of $\mathrm{Au} / \mathrm{CoO}{ }_{x}-\mathrm{TiO}_{2}$.

with the literature data. Au/10 wt. $\% \mathrm{CoO}_{x}-\mathrm{TiO}_{2}$ catalyst had the highest $\mathrm{Au}$ loading among all catalysts, inferring that adding $\mathrm{CoO}_{x}$ could change the isoelectric point of $\mathrm{TiO}_{2}$. It is known [4] that the amount of $\mathrm{Au}$ deposit in DP process was influenced by the isoelectric point of the support.
3.2. $X R D$. Figure 1 shows the $\mathrm{XRD}$ patterns of $\mathrm{Au} / \mathrm{CoO}_{x^{-}}$ $\mathrm{TiO}_{2}$. All catalysts containing $\mathrm{TiO}_{2}$ support showed intense $\mathrm{XRD}$ peaks for anatase and rutile, as expected. It is known that $\mathrm{TiO}_{2}$ P-25 has both anatase and rutile structures. Adding cobalt and $\mathrm{Au}$ and pretreatment did not change its 

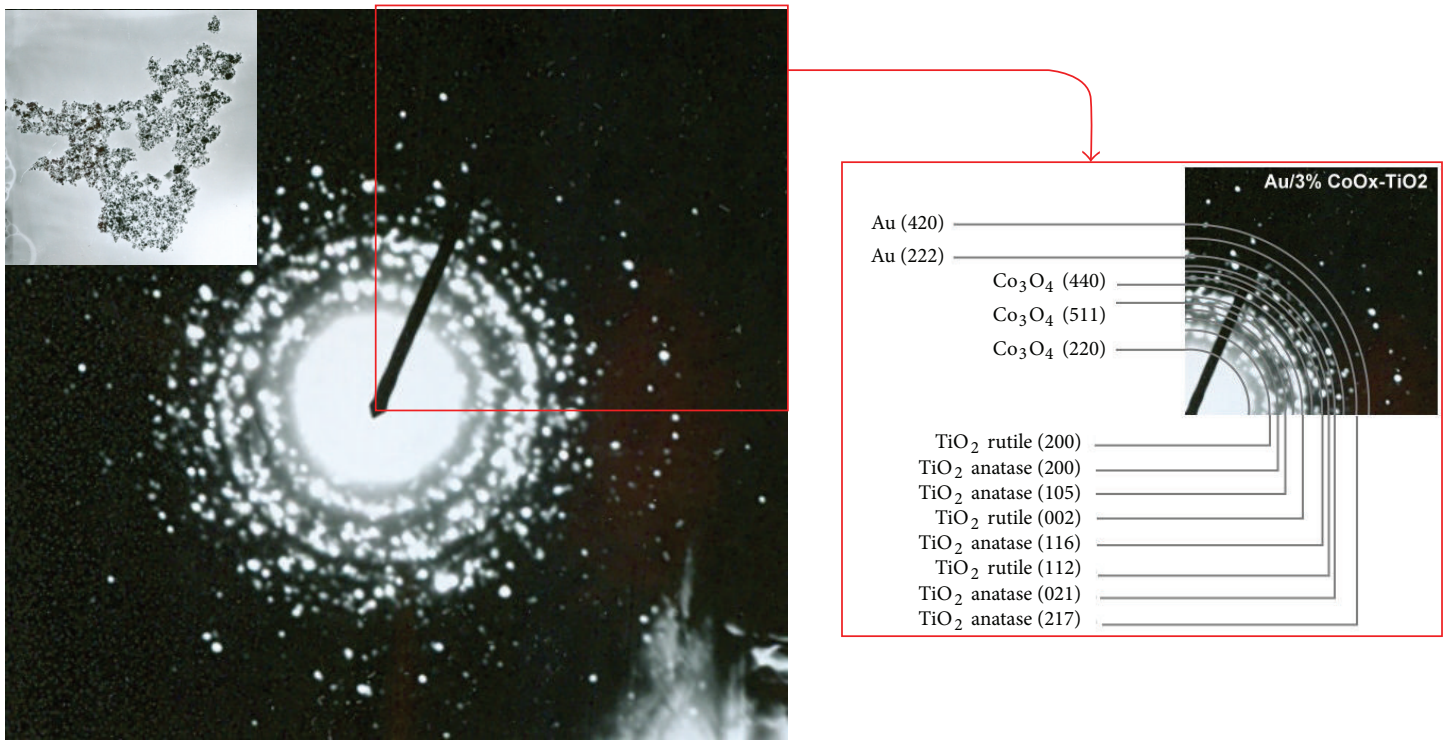

Figure 3: The TEM diffraction pattern of $\mathrm{Au} / 3 \% \mathrm{CoO}_{x}-\mathrm{TiO}_{2}$.

TABLE 2: XPS of binding energy in $\mathrm{Au} / \mathrm{CoO}_{x}-\mathrm{TiO}_{2}$.

\begin{tabular}{|c|c|c|c|c|c|c|c|}
\hline \multirow{2}{*}{ Catalyst } & \multicolumn{2}{|c|}{$\mathrm{Au}$} & \multicolumn{2}{|c|}{ Co } & \multicolumn{2}{|c|}{$\mathrm{Ti}$} & \multirow{2}{*}{$\begin{array}{l}\mathrm{O} \\
1 \mathrm{~s}\end{array}$} \\
\hline & $4 \mathrm{f} 7 / 2$ & $4 \mathrm{f} 5 / 2$ & $2 \mathrm{p} 3 / 2$ & $2 \mathrm{p} 1 / 2$ & $2 \mathrm{p} 3 / 2$ & $2 \mathrm{p} 1 / 2$ & \\
\hline $1 \% \mathrm{CoO}_{x}-\mathrm{TiO}_{2}$ & - & - & 782.9 & 798.5 & 458.9 & 464.7 & 533.0 \\
\hline $5 \% \mathrm{CoO}_{x}-\mathrm{TiO}_{2}$ & - & - & 781.3 & 796.3 & 459.1 & 465.0 & 530.4 \\
\hline $\mathrm{Au} / \mathrm{TiO}_{2}$ & 84.2 & 87.9 & - & - & 459.3 & 465.0 & 530.3 \\
\hline $\mathrm{Au} / 1 \% \mathrm{CoO}_{x}-\mathrm{TiO}_{2}$ & 83.9 & 87.6 & 781.8 & 797.4 & 458.6 & 464.4 & 530.0 \\
\hline $\mathrm{Au} / 3 \% \mathrm{CoO}_{x}-\mathrm{TiO}_{2}$ & 83.4 & 87.1 & 780.3 & 795.5 & 458.4 & 463.9 & 529.9 \\
\hline $\mathrm{Au} / 5 \% \mathrm{CoO}_{x}-\mathrm{TiO}_{2}$ & 82.9 & 86.6 & 779.4 & 794.7 & 458.5 & 464.0 & 529.9 \\
\hline $\mathrm{Au} / \mathrm{TiO}_{2}^{*}$ & 84.1 & 87.8 & - & - & 458.8 & 464.5 & 530.3 \\
\hline $\mathrm{Au} / 1 \% \mathrm{CoO}_{x}-\mathrm{TiO}_{2}{ }^{*}$ & 83.9 & 87.5 & 781.8 & 797.4 & 458.4 & 464.2 & 530.1 \\
\hline $\mathrm{Au} / 3 \% \mathrm{CoO}_{x}-\mathrm{TiO}_{2}{ }^{*}$ & 84.1 & 87.8 & 779.8 & 796.0 & 458.8 & 464.4 & 530.1 \\
\hline $\mathrm{Au} / 5 \% \mathrm{CoO}_{x}-\mathrm{TiO}_{2}{ }^{*}$ & 84.7 & 88.4 & 781.2 & 796.5 & 458.2 & 463.9 & 529.7 \\
\hline
\end{tabular}

${ }^{*}$ After reaction.

crystallinity, because the condition was not harsh. The peaks at $2 \theta=36.85^{\circ}(311), 59.35^{\circ}(511)$, and $65.27^{\circ}$ (440) corresponding to $\mathrm{Co}_{3} \mathrm{O}_{4}$ were observed in the XRD patterns, but the peaks were very weak even in the sample with $10 \mathrm{wt} \% \mathrm{CoO}_{x}$, indicating that $\mathrm{CoO}_{x}$ was a very small particle of $\mathrm{Co}_{3} \mathrm{O}_{4}$. No distinct gold peaks at $2 \theta=38.2^{\circ}$ and $44.5^{\circ}$ were observed, because the particle size of gold was too small to detect.

3.3. TEM. Figure 2 shows the TEM images and the gold particle size distributions of various $\mathrm{Au} / \mathrm{CoO}{ }_{x}-\mathrm{TiO}_{2}$ catalysts. The gold particles in images were observed as dark spots. The TEM images clearly show that the average particle size of $\mathrm{Au}$ in these catalysts was around $3 \mathrm{~nm}$. The results are in accordance with the XRD results, which showed that $\mathrm{Au}$ particle sizes were less than $4 \mathrm{~nm}$. The electron diffraction pattern of $\mathrm{Au} / 3 \% \mathrm{CoO}_{x}-\mathrm{TiO}_{2}$ catalyst is shown in Figure 3. It shows many diffraction rings corresponding to the crystalline lattices of $\mathrm{TiO}_{2}, \mathrm{Co}_{3} \mathrm{O}_{4}$, and $\mathrm{Au}$, in agreement with XRD results.
3.4. HRTEM. The HRTEM images on the sample $\mathrm{Au} / 3 \%$ $\mathrm{CoO}_{x}-\mathrm{TiO}_{2}$ in different spots are shown in Figure 4. Figure 4(a) shows that $\mathrm{CoO}_{x}$ aggregated on $\mathrm{TiO}_{2}$ surface. The gold particles were well dispersed on both $\mathrm{CoO}_{x}$ and $\mathrm{TiO}_{2}$. Figure 4(b) shows that $\mathrm{CoO}_{x}$ and $\mathrm{TiO}_{2}$ had a strong interaction with each other. Figure 4 (c) shows that the gold particle deposited on $\mathrm{CoO}_{x}$, and had strong interaction with $\mathrm{CoO}_{x}-\mathrm{TiO}_{2}$. Figure 4(d) shows that the gold particle deposited on $\mathrm{TiO}_{2}$. It can be observed that the particle size of Au was very small. The Au particle size was about $3 \mathrm{~nm}$. Both TEM and HRTEM diffraction images show the diffraction ring of $\mathrm{Co}_{3} \mathrm{O}_{4}$ (220), confirming the formation of $\mathrm{Co}_{3} \mathrm{O}_{4}$ in these samples.

3.5. XPS. The XPS analysis was carried out on all the samples, and the binding energies and compositions of all the samples were tabulated in Tables 2 and 3. Au $4 \mathrm{f}$ is characterized by the doublet of two spin-orbit components, namely, $\mathrm{Au} 4 \mathrm{f}_{7 / 2}$ and $\mathrm{Au} 4 \mathrm{f}_{5 / 2}$ as shown in Figure 5. The binding energies of 


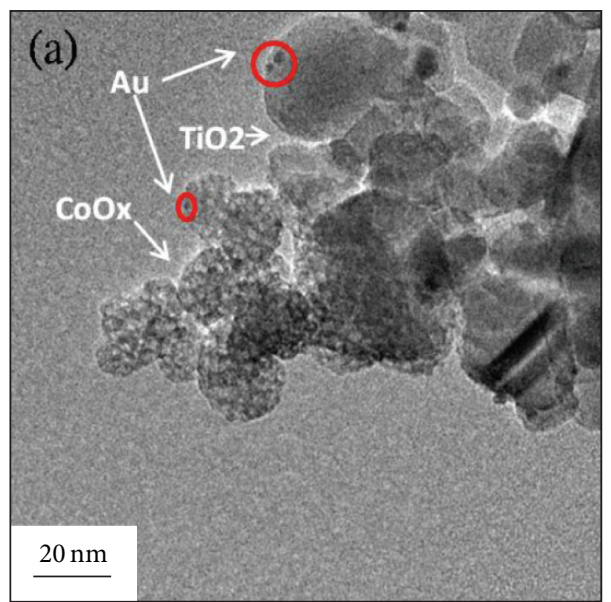

(a)

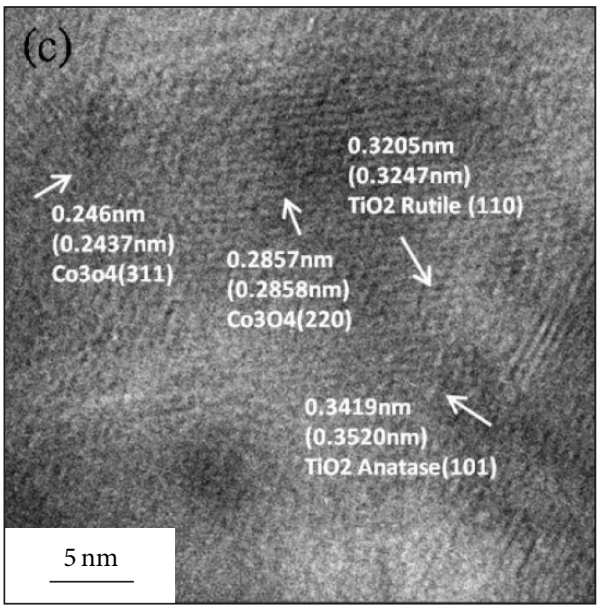

(c)

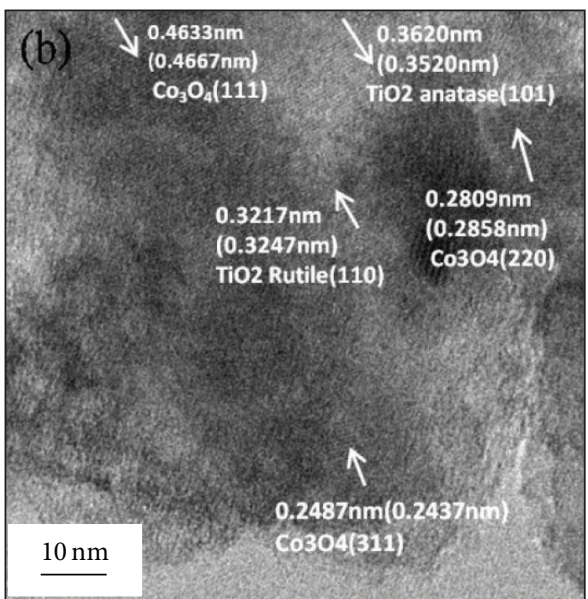

(b)

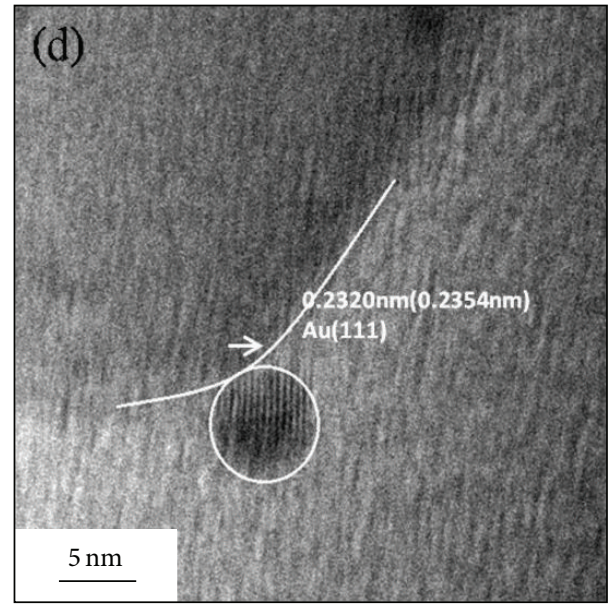

(d)

Figure 4: The HRTEM image of $\mathrm{Au} / 3 \% \mathrm{CoO}_{x}-\mathrm{TiO}_{2}$.

$\mathrm{Au}^{0}$ and $\mathrm{Au}^{+}$in $\mathrm{Au} 4 \mathrm{f}_{7 / 2}$ are 84.0 and $85.5 \mathrm{eV}$, respectively. The binding energy of Au $4 \mathrm{f}$ shifted to a lower one by adding $\mathrm{CoO}_{x}$ in $\mathrm{Au} / \mathrm{TiO}_{2}$, but there was no regular trend with the content of $\mathrm{CoO}_{x}$. The composition of $\mathrm{Au}^{0}$ and $\mathrm{Au}^{+}$did not have the relationship with $\mathrm{CoO}_{x}$ content. The binding energy of $\mathrm{Au} 4 \mathrm{f}_{7 / 2}$ on all of the catalysts shifted to a higher binding energy after reaction. The composition of $\mathrm{Au}^{0}$ and $\mathrm{Au}^{+}$was changed after reaction as shown in Figure 6. The presence of $\mathrm{Au}^{+}$species seems to be effective in promoting activity for $\mathrm{CO}$ oxidation $[10,13]$. The $\mathrm{Au}^{+}$species in $\mathrm{Au} / 3 \% \mathrm{CoO}_{x}-\mathrm{TiO}_{2}$ was abundant compared to other catalysts.

The XPS spectra of Co $2 \mathrm{p}$ of various samples are shown in Figure 7. Co $2 p$ is characterized by the doublet of two spin-orbit components, namely, Co $2 \mathrm{p}_{3 / 2}$ and Co $2 \mathrm{p}_{1 / 2}$. The binding energies of Co $2 \mathrm{p}_{3 / 2}$ and Co $2 \mathrm{p}_{1 / 2}$ were 778 and $793 \mathrm{eV}$ [14]. The binding energy shifted to a lower energy when gold was on the support. The binding energy decreased with increasing the content of $\mathrm{CoO}_{x}$. The XRD results and
TEM diffraction images showed that the $\mathrm{CoO}_{x}$ was in the form of $\mathrm{Co}_{3} \mathrm{O}_{4}$. The XPS spectra of Co $2 \mathrm{p}$ of various samples after reaction are shown in Figure 8.

As shown in Figure 9, the binding energy of lattice oxygen in $\mathrm{TiO}_{2}$ was $529 \mathrm{eV}$ [12-15], and the binding energy of $\mathrm{OH}^{-}$group in $\mathrm{TiO}_{2}$ was $531.8 \mathrm{eV}$ [12-15]. The $\mathrm{O}$ 1s spectra showed no distinction between $\mathrm{Au} / \mathrm{TiO}_{2}$ and $\mathrm{Au} / \mathrm{CoO}_{x^{-}}$ $\mathrm{TiO}_{2}$. Figure 9 (a) shows that $\mathrm{O} 1 \mathrm{~s}$ spectrum of $1 \% \mathrm{CoO}_{x}-\mathrm{TiO}_{2}$ shifted to higher a position, due to the SMSI effect on Co and $\mathrm{TiO}_{2}$, and the binding energy was $\sim 533 \mathrm{eV}$. The binding energy of $\mathrm{O}$ 1s did not change with the content of $\mathrm{CoO}_{x}$. There is no distinction between the samples before and after reaction, as shown in Figure 10.

Ti $2 \mathrm{p}$ is characterized by the doublet of two spin-orbit components, namely, $\mathrm{Ti} 2 \mathrm{p}_{3 / 2}$ and $\mathrm{Ti} 2 \mathrm{p}_{1 / 2}$. The gap between $\mathrm{Ti} 2 \mathrm{p}_{3 / 2}$ and $\mathrm{Ti} 2 \mathrm{p}_{1 / 2}$ is $5-6 \mathrm{eV}$, it is ascribed to $\mathrm{Ti}^{4+}(458.9 \mathrm{eV})$ [16]. As shown in Figure 11, the binding energies of $\mathrm{Ti} 2 \mathrm{p}_{3 / 2}$ and $\mathrm{Ti} 2 \mathrm{p}_{1 / 2}$ of $\mathrm{Au} / \mathrm{CoO}_{x}-\mathrm{TiO}_{2}$ shifted to lower ones than 
TABle 3: XPS analysis in $\mathrm{Au} / \mathrm{CoO}_{x}-\mathrm{TiO}_{2}$.

\begin{tabular}{|c|c|c|c|c|c|c|}
\hline \multirow{2}{*}{ Catalyst } & \multicolumn{2}{|c|}{$\mathrm{Au}$} & \multicolumn{2}{|c|}{ Co } & \multicolumn{2}{|c|}{$\mathrm{O}$} \\
\hline & $\mathrm{Au}^{0}$ & $\mathrm{Au}^{+}$ & $\mathrm{Co}^{2+}$ & $\mathrm{Co}^{3+}$ & $\mathrm{O}^{2-}$ & $\mathrm{OH}^{-}$ \\
\hline $1 \% \mathrm{CoO}_{x}-\mathrm{TiO}_{2}$ & - & - & 72.6 & 27.4 & 84.1 & 15.9 \\
\hline $5 \% \mathrm{CoO}_{x}-\mathrm{TiO}_{2}$ & - & - & 35.2 & 64.8 & 82.1 & 17.9 \\
\hline $\mathrm{Au} / \mathrm{TiO}_{2}$ & 68.5 & 31.5 & - & - & 64.5 & 35.5 \\
\hline $\mathrm{Au} / 1 \% \mathrm{CoO}_{x}-\mathrm{TiO}_{2}$ & 83.4 & 16.6 & 50.8 & 41.2 & 76.9 & 23.1 \\
\hline $\mathrm{Au} / 3 \% \mathrm{CoO}_{x}-\mathrm{TiO}_{2}$ & 56.3 & 43.7 & 49.6 & 50.4 & 89.8 & 10.2 \\
\hline $\mathrm{Au} / 5 \% \mathrm{CoO}_{x}-\mathrm{TiO}_{2}$ & 70.2 & 29.8 & 41.7 & 58.3 & 91.4 & 8.6 \\
\hline $\mathrm{Au} / \mathrm{TiO}_{2}^{*}$ & 92.9 & 7.1 & - & - & 81.5 & 18.5 \\
\hline $\mathrm{Au} / 1 \% \mathrm{CoO}_{x}-\mathrm{TiO}_{2}{ }^{*}$ & 72.9 & 27.1 & 41.2 & 58.8 & 80.4 & 19.6 \\
\hline $\mathrm{Au} / 3 \% \mathrm{CoO}_{x}-\mathrm{TiO}_{2}{ }^{*}$ & 71.8 & 28.2 & 47.8 & 52.2 & 69.5 & 30.5 \\
\hline $\mathrm{Au} / 5 \% \mathrm{CoO}_{x}-\mathrm{TiO}_{2}{ }^{*}$ & 72.4 & 28.6 & 58.3 & 41.7 & 68.5 & 31.5 \\
\hline
\end{tabular}

${ }^{*}$ After reaction.

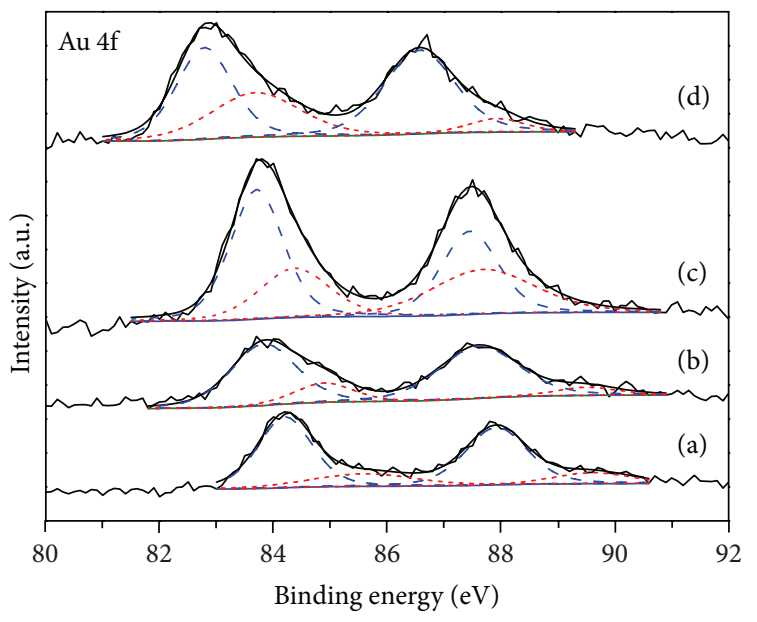

FIGURE 5: XPS of $\mathrm{Au} 4 \mathrm{f}$ spectra of the catalysts before reaction: (a) $\mathrm{Au} / \mathrm{TiO}_{2}$, (b) $\mathrm{Au} / 1 \% \mathrm{CoO}_{x}-\mathrm{TiO}_{2}$, (c) $\mathrm{Au} / 3 \% \mathrm{CoO}_{x}-\mathrm{TiO}_{2}$, and (d) $\mathrm{Au} / 5 \% \mathrm{CoO}_{x}-\mathrm{TiO}_{2}\left(\mathrm{Au}^{0}\right.$ is the dash line, and $\mathrm{Au}^{+}$is the short-dash line).

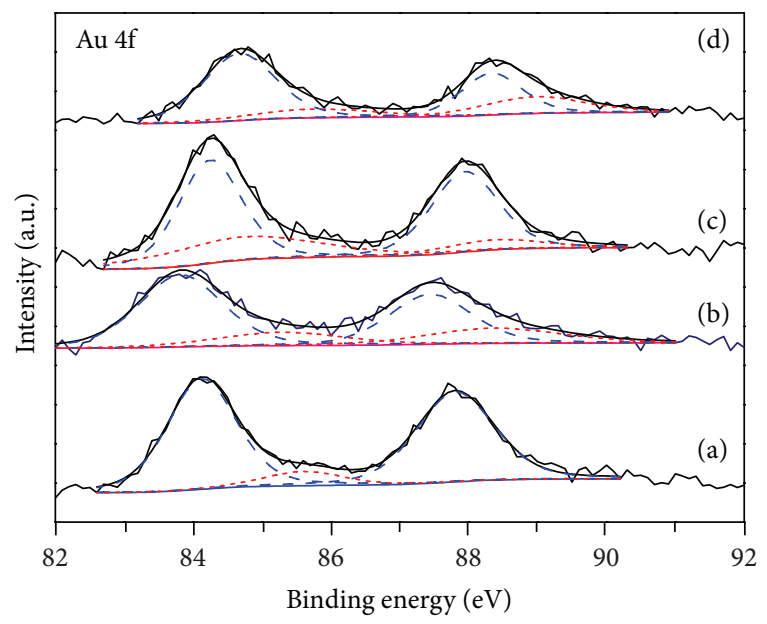

Figure 6: XPS of Au $4 \mathrm{f}$ spectra of the catalysts after reaction: (a) $\mathrm{Au} / \mathrm{TiO}_{2}$, (b) $\mathrm{Au} / 1 \% \mathrm{CoO}_{x}-\mathrm{TiO}_{2}$, (c) $\mathrm{Au} / 3 \% \mathrm{CoO}_{x}-\mathrm{TiO}_{2}$, and (d) $\mathrm{Au} / 5 \% \mathrm{CoO}_{x}-\mathrm{TiO}_{2}\left(\mathrm{Au}^{0}\right.$ is the dash line, and $\mathrm{Au}^{+}$is the short dash line).

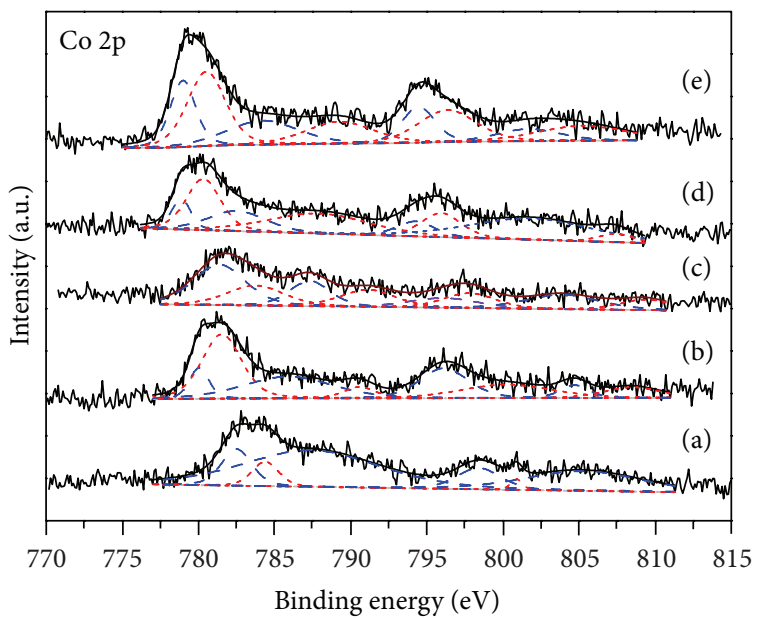

FIGURE 7: XPS of Co 2p spectra of the catalysts before reaction: (a) $1 \% \mathrm{CoO}_{x}-\mathrm{TiO}_{2}$, (b) $5 \% \mathrm{CoO}_{x}-\mathrm{TiO}_{2}$, (c) $\mathrm{Au} / 1 \% \mathrm{CoO}_{x}-\mathrm{TiO}_{2}$, (d) $\mathrm{Au} / 3 \% \mathrm{CoO}_{x}-\mathrm{TiO}_{2}$, and (e) $\mathrm{Au} / 5 \% \mathrm{CoO}_{x}-\mathrm{TiO}_{2},\left(\mathrm{Co}^{2+}\right.$ is the dash line, and $\mathrm{Co}^{3+}$ is the short dash line).

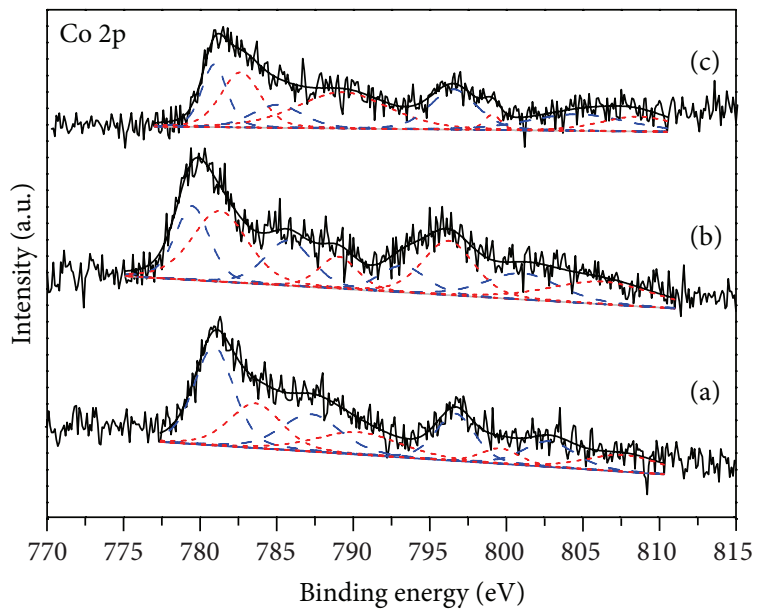

FIGURE 8: XPS of Co $2 p$ spectra of the catalysts after reaction: (a) $\mathrm{Au} / 1 \% \mathrm{CoO}_{x}-\mathrm{TiO}_{2}$, (b) $\mathrm{Au} / 3 \% \mathrm{CoO}_{x}-\mathrm{TiO}_{2}$, and (c) $\mathrm{Au} / 5 \% \mathrm{CoO}_{x}-$ $\mathrm{TiO}_{2}\left(\mathrm{Co}^{2+}\right.$ is the dash line, and $\mathrm{Co}^{3+}$ is the short dash line $)$. 


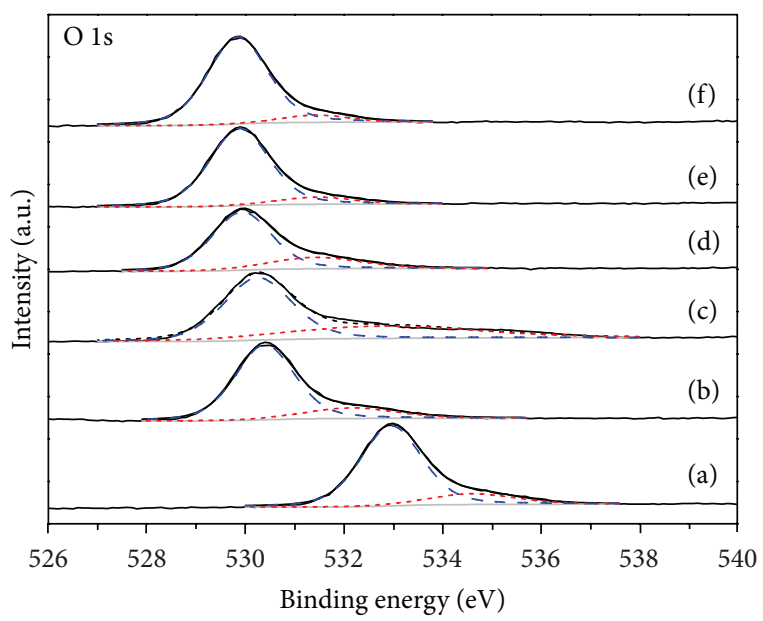

FIGURE 9: XPS of $\mathrm{O}$ 1s spectra of the catalysts before reaction: (a) $1 \% \mathrm{CoO}_{x}-\mathrm{TiO}_{2}$, (b) $5 \% \mathrm{CoO}_{x}-\mathrm{TiO}_{2}$, (c) $\mathrm{Au} / \mathrm{TiO}_{2}$, (d) $\mathrm{Au} / 1 \% \mathrm{CoO}_{x^{-}}$ $\mathrm{TiO}_{2}$, (e) $\mathrm{Au} / 3 \% \mathrm{CoO}_{x}-\mathrm{TiO}_{2}$, and (f) $\mathrm{Au} / 5 \% \mathrm{CoO}_{x}-\mathrm{TiO}_{2}\left(\mathrm{O}^{2-}\right.$ is the blue dash line and $\mathrm{OH}^{-}$is the red dash line).

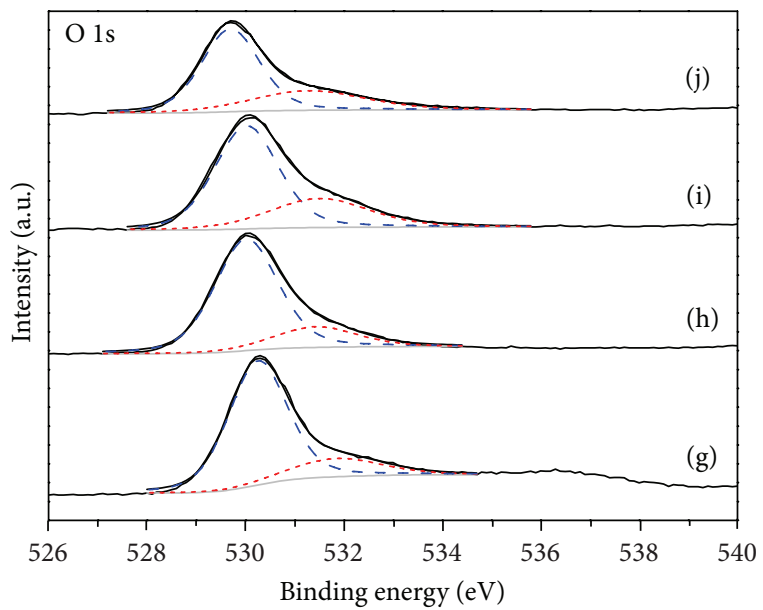

FIgURE 10: XPS of $\mathrm{O}$ 1s spectra of the catalysts after reaction: (a) $\mathrm{Au} / \mathrm{TiO}_{2}$, (b) $\mathrm{Au} / 1 \% \mathrm{CoO}_{x}-\mathrm{TiO}_{2}$, (c) $\mathrm{Au} / 3 \% \mathrm{CoO}_{x}-\mathrm{TiO}_{2}$, and (d) $\mathrm{Au} / 5 \% \mathrm{CoO}_{x}-\mathrm{TiO}_{2}\left(\mathrm{O}^{2-}\right.$ is the blue dash line and $\mathrm{OH}^{-}$is the red dash line).

those of $\mathrm{Au} / \mathrm{TiO}_{2}$, indicating the interaction of $\mathrm{CoO}_{x}$ with $\mathrm{TiO}_{2}$. The Ti $2 \mathrm{p}$ spectra of the samples did not change after reaction as shown in Figure 12.

3.6. $\mathrm{CO}$ Oxidation. All of the $\mathrm{Au} / \mathrm{CoO}_{x}-\mathrm{TiO}_{2}$ catalysts were very active for $\mathrm{CO}$ oxidation. Figure 13 shows that the addition of $\mathrm{CoO}_{x}$ to $\mathrm{Au} / \mathrm{TiO}_{2}$ could enhance the activity of the catalyst significantly. At weight hourly space velocity (WHSV) of $120,000 \mathrm{~mL} / \mathrm{gh}, \mathrm{CO}$ conversions on all $\mathrm{Au} /$ $\mathrm{CoO}_{x}-\mathrm{TiO}_{2}$ catalysts reach $100 \%$ even at $308 \mathrm{~K}$. In contrast, $\mathrm{Au} / \mathrm{TiO}_{2}$ was not active at room temperature. It should be noted that only $0.7 \mathrm{wt} . \%$ Au was used in this study. In order to differentiate the activities of these catalysts, a higher WHSV of $180,000 \mathrm{~mL} / \mathrm{h} \mathrm{g}$ was used. Figure 14 shows that the best catalyst was $\mathrm{Au} / 3 \% \mathrm{CoO}_{x}-\mathrm{TiO}_{2}$. $\mathrm{Au} / 3 \% \mathrm{CoO}_{x}-\mathrm{TiO}_{2}$ could

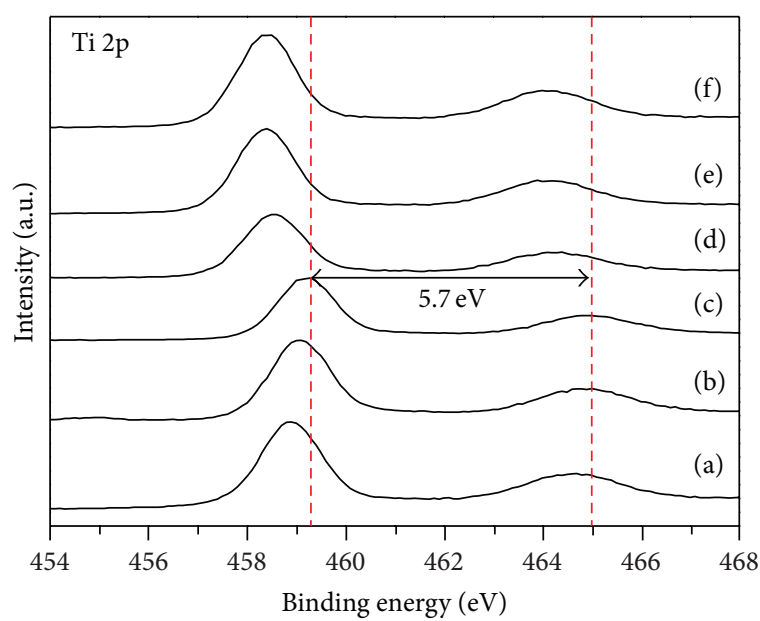

FIGURE 11: XPS of Ti 2p spectra of the catalysts before reaction: (a) $1 \% \mathrm{CoO}_{x}-\mathrm{TiO}_{2}$, (b) $5 \% \mathrm{CoO}_{x}-\mathrm{TiO}_{2}$, (c) $\mathrm{Au} / \mathrm{TiO}_{2}$, (d) $\mathrm{Au} / 1 \% \mathrm{CoO}_{x^{-}}$ $\mathrm{TiO}_{2}$, (e) $\mathrm{Au} / 3 \% \mathrm{CoO}_{x}-\mathrm{TiO}_{2}$, and (f) $\mathrm{Au} / 5 \% \mathrm{CoO}_{x}-\mathrm{TiO}_{2}$.

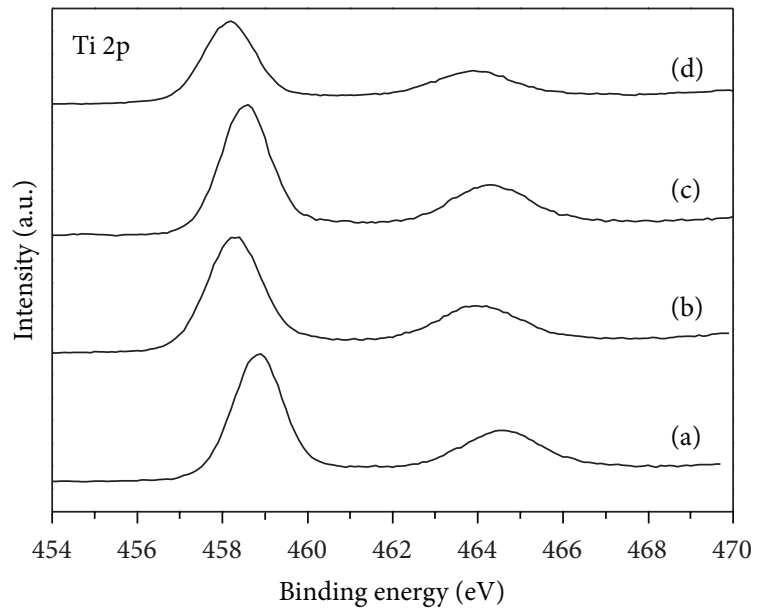

FIGURE 12: XPS of Ti $2 \mathrm{p}$ spectra of the catalysts after reaction: (a) $\mathrm{Au} / \mathrm{TiO}_{2}$, (b) $\mathrm{Au} / 1 \% \mathrm{CoO}_{x}-\mathrm{TiO}_{2}$, (c) $\mathrm{Au} / 3 \% \mathrm{CoO}_{x}-\mathrm{TiO}_{2}$, and (d) $\mathrm{Au} / 5 \% \mathrm{CoO}_{x}-\mathrm{TiO}_{2}$.

oxidize CO completely at low temperature, and the result was similar with Cunningham et al. [17]. It contained the highest gold loading and the highest content of active sites $\left(\mathrm{Au}^{+}\right)$. Our results were different from that reported by Haruta [1] for $\mathrm{Au} / \mathrm{TiO}_{2}$, because they used a different amount of gold. $1 \mathrm{wt} . \% \mathrm{Au} / \mathrm{TiO}_{2}$ was used in this study, and $10 \mathrm{wt} . \% \mathrm{Au} / \mathrm{TiO}_{2}$ was used in their study [1]. It should be noted that $\mathrm{Co}_{3} \mathrm{O}_{4}$ is an active catalyst for CO oxidation $[18,19]$, but not at ambient condition. By adding $\mathrm{Au}$ on the $\mathrm{Co}_{3} \mathrm{O}_{4}$, the catalyst became very active at ambient condition. The results clearly demonstrated that $\mathrm{Au} / \mathrm{CoO}_{x}-\mathrm{TiO}_{2}$ catalyst is a promising catalyst for $\mathrm{CO}$ oxidation at ambient condition. The small $\mathrm{Au}$ particle size, narrow Au particle size distribution, and well $\mathrm{Au}$ dispersions on $\mathrm{CoO}_{x}-\mathrm{TiO}_{2}$ support play the key roles. The presence of $\mathrm{CoO}_{x}$ could stabilize the nano Au particles, resulting in high activity of the catalyst [20-25]. 


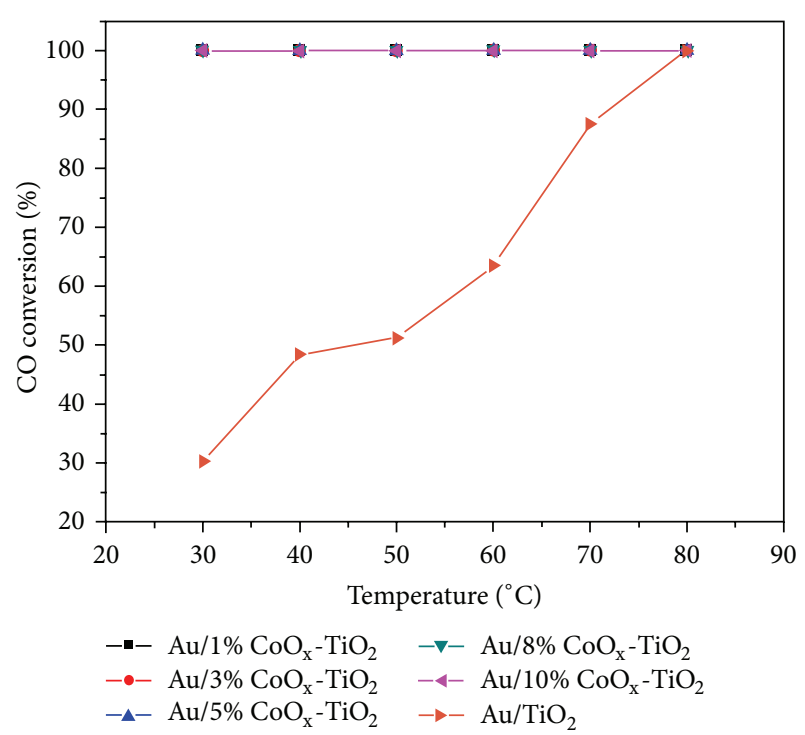

Figure 13: The $\mathrm{CO}$ conversion on $\mathrm{Au} / \mathrm{CoO}_{x}-\mathrm{TiO}_{2}$ Reaction condition: $1 \%$ CO in air, WHSV $=120,000 \mathrm{~mL} / \mathrm{hg}$.

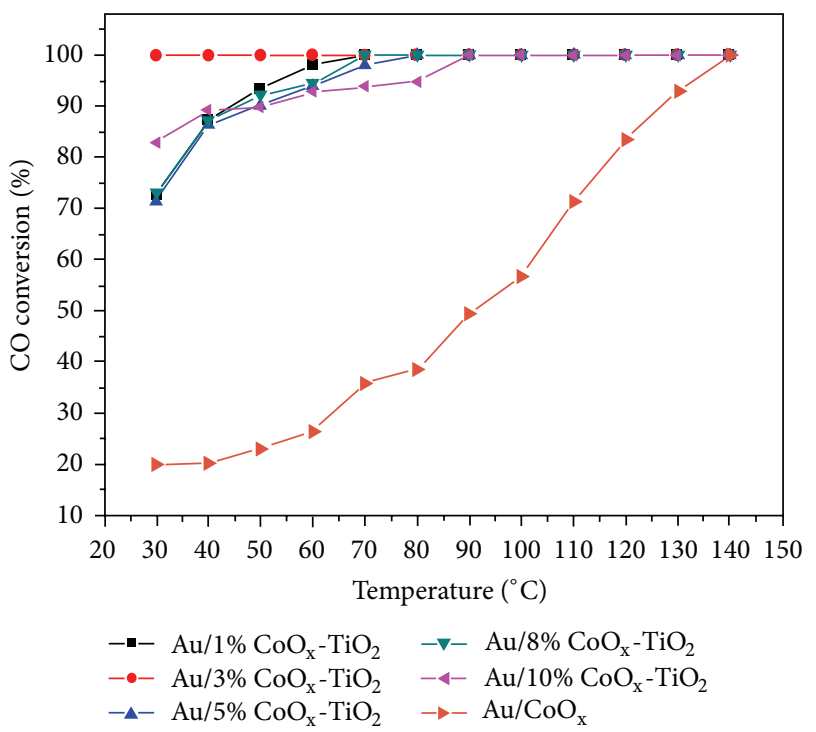

Figure 14: The $\mathrm{CO}$ conversion on $\mathrm{Au} / \mathrm{CoO}_{x}-\mathrm{TiO}_{2}$ Reaction condition: $1 \%$ CO in air, WHSV $=180,000 \mathrm{~mL} / \mathrm{hg}$.

\section{Conclusion}

$\mathrm{CoO}_{x}-\mathrm{TiO}_{2}$ supports were prepared by incipient wetness impregnation method. Au catalysts were prepared by DP method to load $\mathrm{Au}$ on these supports. The results showed small Au particle size $(2.4-3.3 \mathrm{~nm})$, narrow Au particle size distribution, and well $\mathrm{Au}$ dispersions on these catalysts. $\mathrm{Au} / 10 \% \mathrm{CoO}_{x}-\mathrm{TiO}_{2}$ had the maximum gold loading. $\mathrm{CoO}$ and $\mathrm{TiO}_{2}$ had interactions between each other. Adding Co into $\mathrm{Au} / \mathrm{TiO}_{2}$ could increase the activity of $\mathrm{CO}$ oxidation. CO chemisorbed on octahedrally coordinated cobalt sites, while tetrahedrally coordinated cobalt sites were inactive for $\mathrm{CO}$ adsorption. It could enhance the activity of $\mathrm{CO}$ oxidation. Comparing the other catalysts in this study, the $\mathrm{Au} / 3 \% \mathrm{CoO}_{x}-\mathrm{TiO}_{2}$ catalyst had the highest $\mathrm{CO}$ conversion at a low temperature. It contained the highest gold loading and the highest content of active sites $\left(\mathrm{Au}^{+}\right)$.

\section{References}

[1] M. Haruta, "Size- and support-dependency in the catalysis of gold," Catalysis Today, vol. 36, no. 1, pp. 153-166, 1997.

[2] M. Haruta, "Gold as a low-temperature oxidation catalyst: factors controlling activity and selectivity," Studies in Surface Science and Catalysis, vol. 110, pp. 123-134, 1997.

[3] M. Haruta, T. Kobayashi, H. Sano, and Yamada, "Novel gold catalysts for the oxidation of carbon monoxide at a temperature far below 0 'C," Chemical Letters, vol. 10, pp. 405-408, 1987.

[4] M. Haruta, "Nanoparticulate gold catalysts for low-temperature CO oxidation," Journal of New Materials for Electrochemical Systems, vol. 7, no. 3, pp. 163-172, 2004.

[5] Y. F. Yang, P. Sangeetha, and Y. W. Chen, " $\mathrm{Au} / \mathrm{TiO}_{2}$ catalysts prepared by photo-deposition method for selective $\mathrm{CO}$ oxidation in $\mathrm{H}_{2}$ stream," International Journal of Hydrogen Energy, vol. 34, no. 21, pp. 8912-8920, 2009.

[6] X. Xie, Y. Li, Z. Q. Liu, M. Haruta, and W. Shen, "Lowtemperature oxidation of $\mathrm{CO}$ catalysed by $\mathrm{Co}_{3} \mathrm{O}_{4}$ nanorods," Nature, vol. 458, no. 7239, pp. 746-749, 2009.

[7] Y. F. Yang, P. Sangeetha, and Y. W. Chen, "Au/FeO $-\mathrm{TiO}_{2}$ catalysts for the preferential oxidation of $\mathrm{CO}$ in a $\mathrm{H}_{2}$ stream," Industrial and Engineering Chemistry Research, vol. 48, no. 23, pp. 10402-10407, 2009.

[8] T. J. Huang and D. H. Tsai, "CO oxidation behavior of copper and copper oxides," Catalysis Letters, vol. 87, no. 3-4, pp. 173178, 2003.

[9] K. Y. Ho and K. L. Yeung, "Effects of ozone pretreatment on the performance of $\mathrm{Au} / \mathrm{TiO}_{2}$ catalyst for $\mathrm{CO}$ oxidation reaction," Journal of Catalysis, vol. 242, no. 1, pp. 131-141, 2006.

[10] M. M. Schubert, S. Hackenberg, A. C. Van Veen, M. Muhler, V. Plzak, and J. J. Behm, "CO oxidation over supported gold catalysts- "Inert" and "active" support materials and their role for the oxygen supply during reaction," Journal of Catalysis, vol. 197, no. 1, pp. 113-122, 2001.

[11] B. Schumacher, Y. Denkwitz, V. Plzak, M. Kinne, and R. J. Behm, "Kinetics, mechanism, and the influence of $\mathrm{H}_{2}$ on the $\mathrm{CO}$ oxidation reaction on $\mathrm{au} / \mathrm{TiO}_{2}$ catalyst," Journal of Catalysis, vol. 224, no. 2, pp. 449-462, 2004.

[12] L. H. Chang, Y. W. Chen, and N. Sasirekha, "Preferential oxidation of carbon monoxide in hydrogen stream over $\mathrm{Au} / \mathrm{MgO}_{x}$ $\mathrm{TiO}_{2}$ catalysts," Industrial and Engineering Chemistry Research, vol. 47, no. 12, pp. 4098-4105, 2008.

[13] M. P. Casaletto, A. Longo, A. Martorana, A. Prestianni, and A. M. Venezia, "XPS study of supported gold catalysts: the role of $\mathrm{Au}^{0}$ and $\mathrm{Au}^{+}$species as active sites," Surface and Interface Analysis, vol. 38, no. 4, pp. 215-218, 2006.

[14] J. F. Moulder, W. F. Stickle, P. E. Sobol, and K. E. Bomben, Handbook of X-Ray Photoelectron Spectroscopy, Physical Electronics, 1995.

[15] M. Haruta, S. Tsubota, T. Kobayashi, H. Kageyama, M. J. Genet, and B. Delmon, "Low-Temperature Oxidation of CO over Gold Supported on $\mathrm{TiO}_{2}, \alpha-\mathrm{Fe}_{2} \mathrm{O}_{3}$, and $\mathrm{Co}_{3} \mathrm{O}_{4}$," Journal of Catalysis, vol. 144, no. 1, pp. 175-192, 1993. 
[16] D. Gonbeau, C. Guimon, G. Pfister-Guillouzo, A. Levasseur, G. Meunier, and R. Dormoy, "XPS study of thin films of titanium oxysulfides," Surface Science, vol. 254, no. 1-3, pp. 81-89, 1991.

[17] D. A. H. Cunningham, T. Kobayashi, N. Kamijo, and M. Haruta, "Influence of dry operating conditions: observation of oscillations and low temperature CO oxidation over $\mathrm{Co}_{3} \mathrm{O}_{4}$ and $\mathrm{Au} / \mathrm{Co}_{3} \mathrm{O}_{4}$ catalysts," Catalysis Letters, vol. 25, no. 3-4, pp. 257264, 1994.

[18] Y. F. Y. Yao, "The oxidation of hydrocarbons and CO over metal oxides. III. $\mathrm{Co}_{3} \mathrm{O}_{4}$," Journal of Catalysis, vol. 33, no. 1, pp. 108$122,1974$.

[19] D. Perti and R. L. Kabel, "Kinetics of CO oxidation over $\mathrm{Co}_{3} \mathrm{O}_{4} / \mathrm{Al}_{2} \mathrm{O}_{3}$," AIChE Journal, vol. 31, pp. 1420-1440, 1985.

[20] P. Sangeetha, B. Zhao, and Y. W. Chen, "Au/CuO ${ }_{x}-\mathrm{TiO}_{2}$ catalysts for preferential oxidation of CO in hydrogen stream," Industrial and Engineering Chemistry Research, vol. 49, no. 5, pp. 20962102, 2010.

[21] Y. W. Chen, D. S. Lee, and H. J. Chen, "Preferential oxidation of $\mathrm{CO}$ in $\mathrm{H} 2$ stream on $\mathrm{Au} / \mathrm{ZnO}-\mathrm{TiO}_{2}$ catalysts," International Journal of Hydrogen Energy, vol. 37, pp. 15140-15155, 2012.

[22] Y. W. Chen, H. J. Chen, and D. S. Lee, " $\mathrm{Au} / \mathrm{Co}_{3} \mathrm{O}_{4}-\mathrm{TiO}_{2}$ catalysts for preferential oxidation of $\mathrm{CO}$ in $\mathrm{H}_{2}$ stream," Journal of Molecular Catalysis A, vol. 363- 364, pp. 470-480, 2012.

[23] D. Tsukamato, Y. Shiraishi, Y. Sugano, S. Ichikawa, S. Tanaka, and T. Hirai, "Gold nanoparticles located at the interface of anatase/rutile $\mathrm{TiO}_{2}$ particles as active plasmonic photocatalysts for aerobic oxidation," Journal of American Chemical Society, vol. 134, pp. 6309-6315, 2012.

[24] Y. Kuwauchi, H. Yoshida, T. Akita, M. Haruta, and S. Takeda, "Intrinsic catalytic structure of gold nanoparticles supported on $\mathrm{TiO}_{2}$," Angew Chemistry International Edition, vol. 351, pp. 7729-7733, 2012.

[25] L. F. Liotta, "New frontiers in gold catalyzed reactions," Catalysts, vol. 2, pp. 299-302, 2012. 

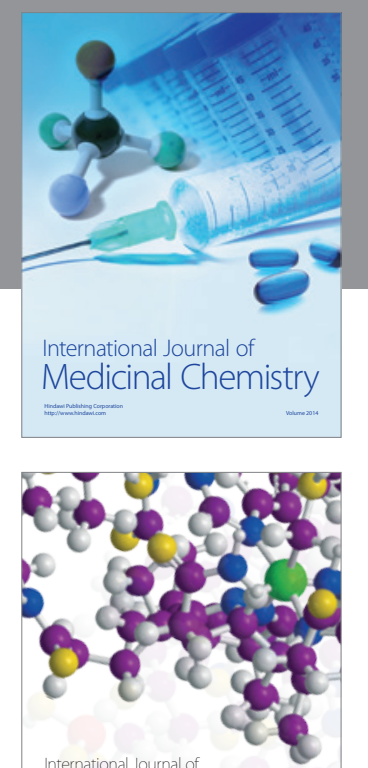

\section{Carbohydrate} Chemistry

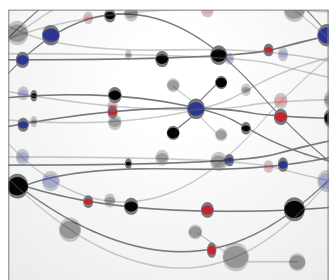

The Scientific World Journal
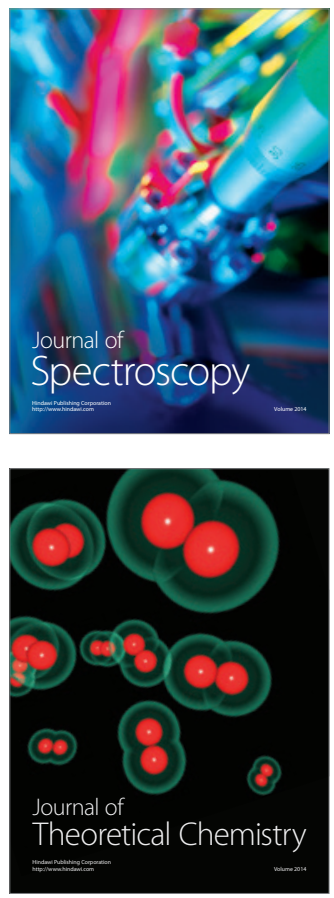
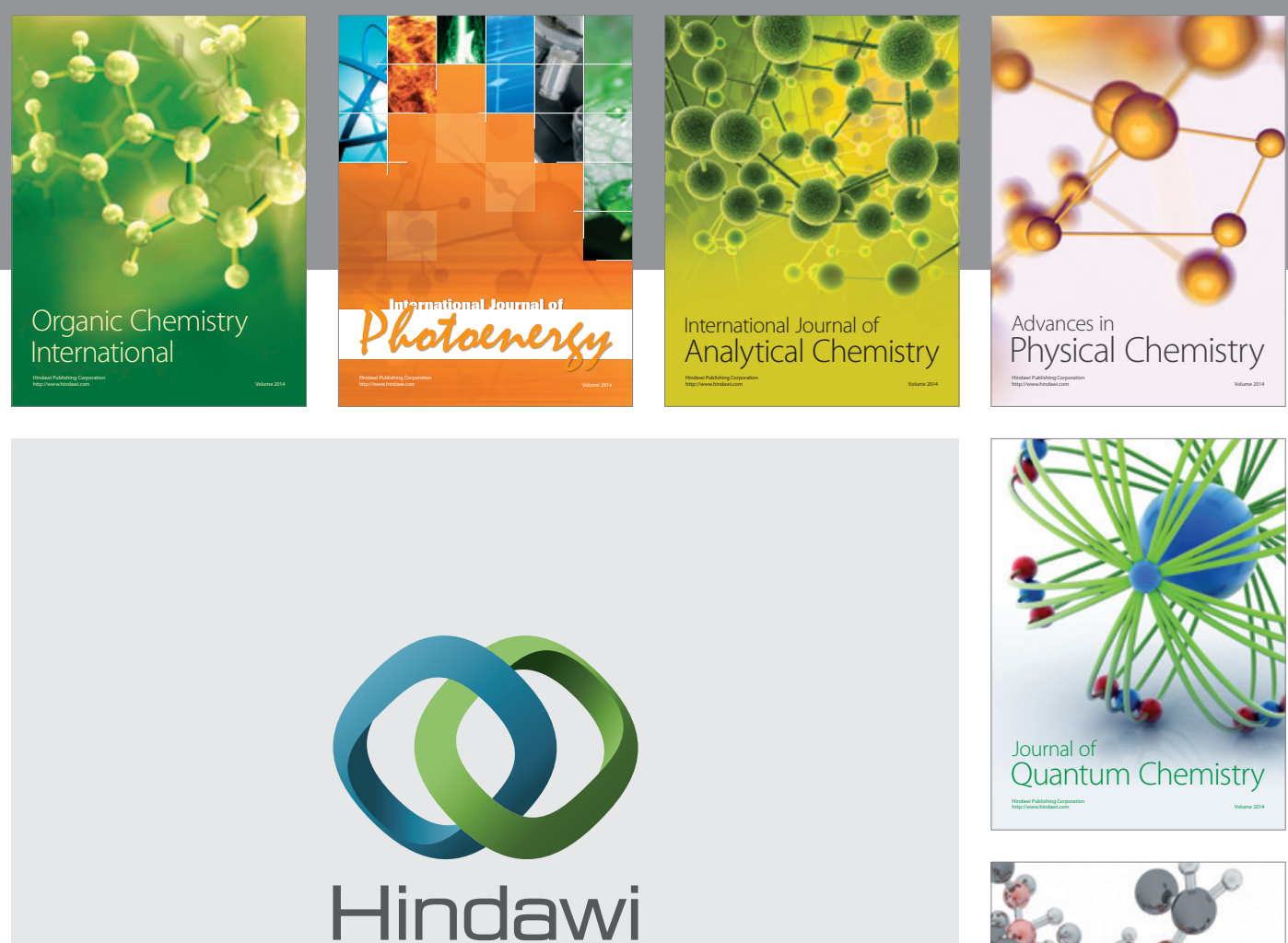

Submit your manuscripts at

http://www.hindawi.com

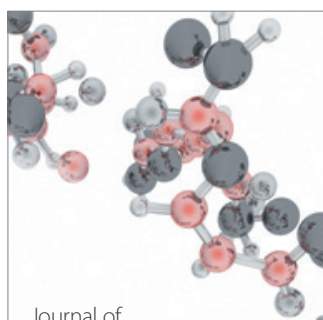

Analytical Methods

in Chemistry

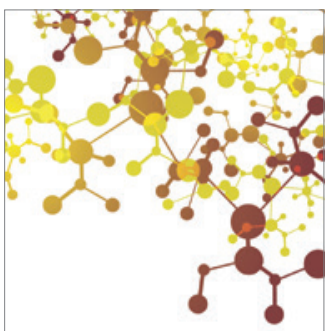

Journal of

Applied Chemistry

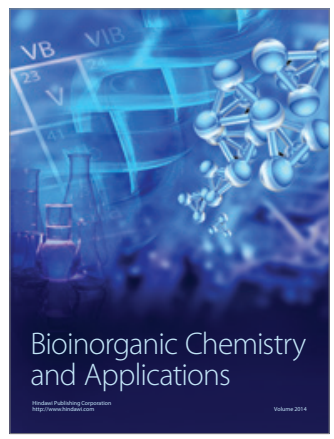

Inorganic Chemistry
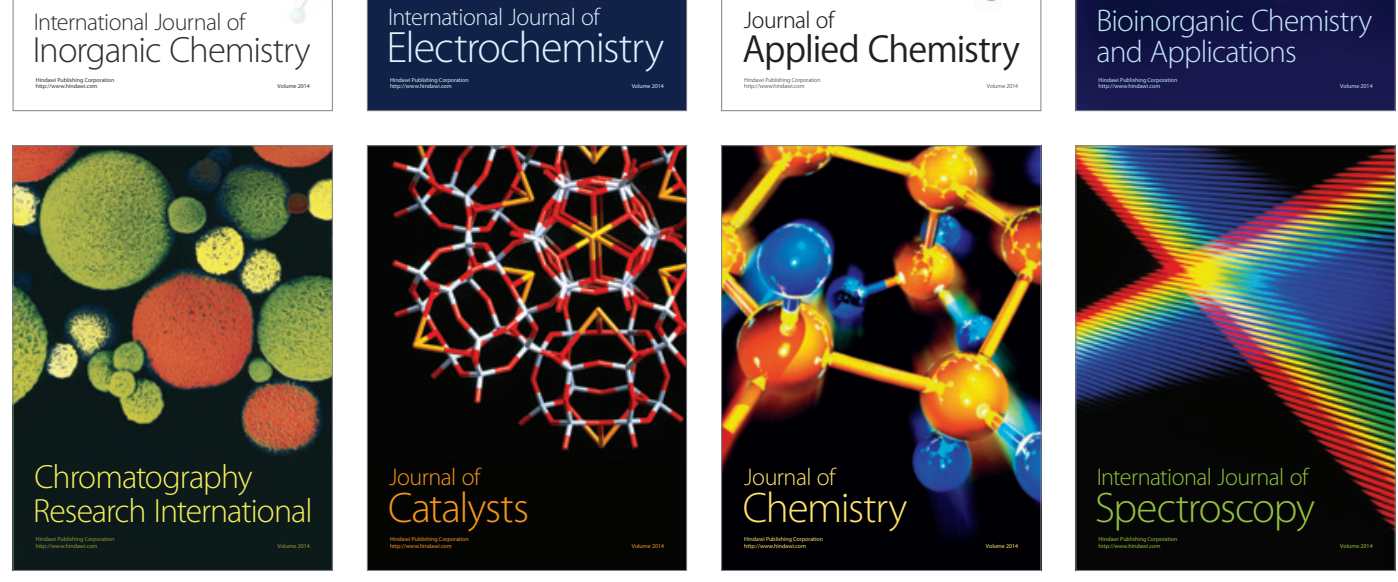